Chirurgia (2019) 114: 115-120

No. 1, January - February

Copyright $\odot$ Celsius

http://dx.doi.org/10.21614/chirurgia.114.1.115

\title{
Day-case Surgery in the Context of Inguinal Hernia Repair by the Modified Lichtenstein Technique - A Single Centre Experience
}

\author{
Ciprian Tanasescu, Mihai Faur, Dan Sabau
}

Lucian Blaga" University of Sibiu, Faculty of Medicine, Surgical Clinic, Department III, Sibiu Romania

Corresponding author:

Mihai Faur, MD

Lucian Blaga" University of Sibiu

E-mail: mishu.faur@yahoo.com

\section{Rezumat}

Experienta noastră în chirurgia de o zi a herniei inghinale prin tehnica Lichtenstein (anestezie locală și incizie transversală)

Existența unui mare numãr de tehnici chirurgicale descrise pentru cura herniei inghinale practicate şi publicate în diferite articole şi tratate, provoacă o adevarată confuzie asupra chirurgului tânăr, care se vede nevoit de cele mai multe ori să practice tehnica dobândită în clinica în care îşi face rezidențiatul, defapt cea pe care a văzut-o de cele mai multe ori. De asemenea anatomia regiunii inghinale a suscitat numeroase interpretări datorită dispunerii spațiale, în trei planuri a elementelor, precum şi datorită necesității obținerii din punct de vedere chirurgical a unor structuri de rezistență cu înaltă valoare funcțional. Studiul retrospectiv a fost realizat în cadrul Clinicii Proctoven din Sibiu, pe o perioadă de 5 ani. Au fost evaluați 219 pacienți cu diagnosticul de hernie inghinală, operați prin tehnica chirurgicală Lichtenstein, între martie 2011 şi martie 2016. Tehnica Lichtenstein este considerată a fi extrem de bine tolerată de pacienți, spitalizarea mai puțin de 3 ore constituind un alt avantaj, şi totodată dispune de rezultate satisfăcătoare atât de scurtă cât şi de lungă durată.

Cuvinte cheie: hernie inghinală, tehnica Lichtenstein modificată, chirurgie de o zi, anestezie locală, anestezie intravenoasă, conceptul de Fast-track 
cure, might create confusion to the young surgeon, who is often forced to perform the technique acquired in the Department where he/she was trained. Also, the anatomy of the inguinal region has given rise to numerous interpretations due to the spatial layout of the elements, as well as to the necessity of obtaining high-functional resistance anatomical structures. The retrospective study was conducted at the Proctoven Clinic in Sibiu for a period of 5 years. 219 patients diagnosed of inguinal hernia, were operated by the Lichtenstein technique between March 2011 and March 2016. We consider the practice of the Lichtenstein procedure for our patients to be extremely feasible, very well tolerated, with less than 3 hours hospitalization, with good short and long term results.

Key words: inguinal hernia, modified Lichtenstein, one day surgery, local anesthesia, intravenous anesthesia, Fast-track surgery concept

\section{Introduction}

Surgery for inguinal hernia is one of the most common interventions in the surgical service.

The plethora of surgical techniques described for inguinal hernia cure, might create confusion to the young surgeon, who is often forced to perform the technique acquired in the Department where he/she was trained (1-3).

Unlike for other surgical indications for operations where the technique is well coded, inguinal hernia repair techniques described in current literature can vary significantly $(4-5)$.

Also, the anatomy of the inguinal region has given rise to numerous interpretations due to the spatial layout of the elements, as well as to the necessity of surgically obtaining high-functional resistance anatomical structures $(6,7)$.

\section{Material and Method}

Putting together many notions of anatomy, many surgical techniques, and especially the experience of the surgical centers we managed to improve and adapt Lichtenstein technique, which We consider perfectly suited for any kind of inguinal hernia (external, oblique, direct) in ambulatory surgery patients, who can actually be admitted for a maximum of 3 hours.

The most common type of inguinal hernia is the external oblique hernia, defined as the protrusion of the abdominal viscera through the lateral slant of the inguinal region, following the shaft of the inguinal canal through its entire length. The direct inguinal hernia is the second most frequent type (c. $20 \%$ of inguinal hernias), and can be defined as the protrusion of the abdominal viscera through the middle of the inguinal floor (6).

The group of patients are male and woman with age between 20 and 90 years old, with chronic diseases, only with external oblique and direct hernias.

From the study we excluded the internal oblique and complicated hernias, and childrens and young people who have not completed their growth process.

\section{Tehnique Description}

All cases received a combination of the regional block anaesthesia (ilio-lingual nerve block with local infiltration) (Fig. 1) and the general intravenous anaesthesia, the patients, being able to walk from the operating table back to the ward, something unusual for the classic Lichtenstein technique.

The ilio-inguinal nerve block was performed in the following: $2 \mathrm{~cm}$ from the anterior iliac spine on the bispina line, and then mark the spot; on the perpendicular onto the bispina line that passes through to the marked spot we go another $2 \mathrm{~cm}$ cranially, and mark again. At this point, the needle penetrated perpendicularly into the skin, the subcutaneous tissue and the muscle tissue, and $10 \mathrm{ml}$ of $1 \%$ lidocaine is injected in all directions. 
Propofol was used for induction and maintenance. One of its main advantages is the ease and speed with which the patient wakes up, and also a low incidence of postoperative nausea and vomiting (8-10).

The laryngeal mask was only used when there was a great need for muscle relaxation, avoiding tracheal intubation and extubation, which allows a faster running of the cases (1,11-13). Recovery after anaesthesia is a very important parameter in one-day surgery $(1,14)$. Non-steroidal anti-inflammatory drugs, (eg, diclofenac and ketorol) were routinely used in order to provide postoperative analgesia.

After performing both the regional block and infiltration of the skin with a $1 \%$ lidocaine solution, a $5 \mathrm{~cm}$-long incision was undertaken. The incision is practiced transversally, parallel to the bispinous line, centered on the inguinal canal, approximately $2 \mathrm{~cm}$ from the superficial orifice of the inguinal canal, whereas the classic Lichtenstein incision is oblique (Fig. 2).

The advantages of this incision are mainly aesthetic, as the incision is masked in the abdominal folds, and it decreases the risk of keloid scar. There are, also, tactical advantages, as (it is much easier to pull cranially and caudally, depending of the area in which we work. This offers an additional wall resistance on a different line than the sinewy aponeurosis suture).

The spermatic cord is dislocated, the posterior wall of the inguinal canal is released, the hernia sac is isolated and treated, accompanied by the resection of the hernia lipoma. After controlling the content of the hernia sac, the sac is ligated, followed by its resection (1) (Fig. 3).

The cremaster muscle is resected routinely as per our protocol, especially its lateral beam, which might potentially block the suture of the polypropylene prosthesis at the level of the crural arcade of the deep inguinal canal ring (Fig. 4).

The prosthesis of the posterior inguinal canal wall consisted of a monofilament polypropylene mesh with large pores. The prosthesis was fixed with separate points of suture at the level of the pubic spine, then the lower edge is fixed to the lacunar ligament and to the posterior arch of the crural arch, up to the deep inguinal canal ring with a running suture of 3.0 Biopro, non-absorbable. The upper edge of the prosthesis was sutured to the conjoint tendon with interrupted sutures.

The external edge of the prosthesis surrounds the spermatic cord so that the orifice of the mesh circumscribes the spermatic cord.

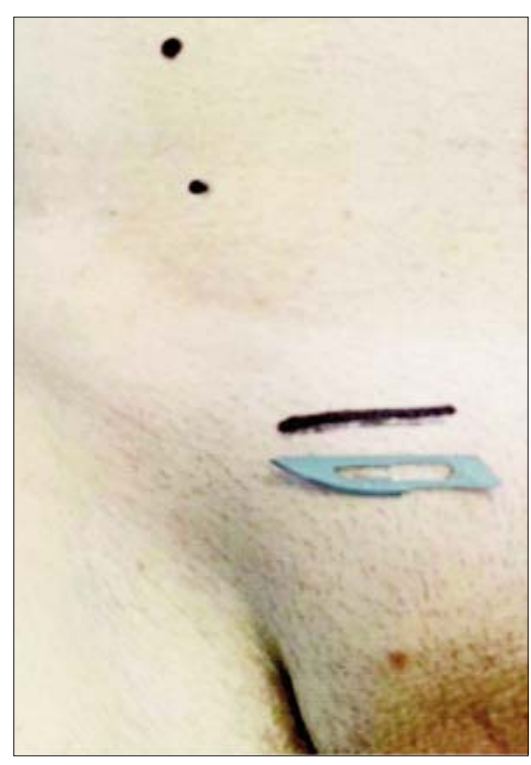

Figure 1. Ilio-inguinal nerve block

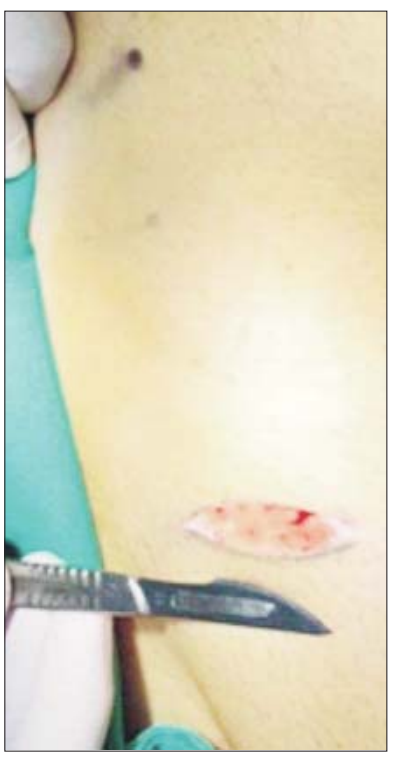

Figure 2. The incision

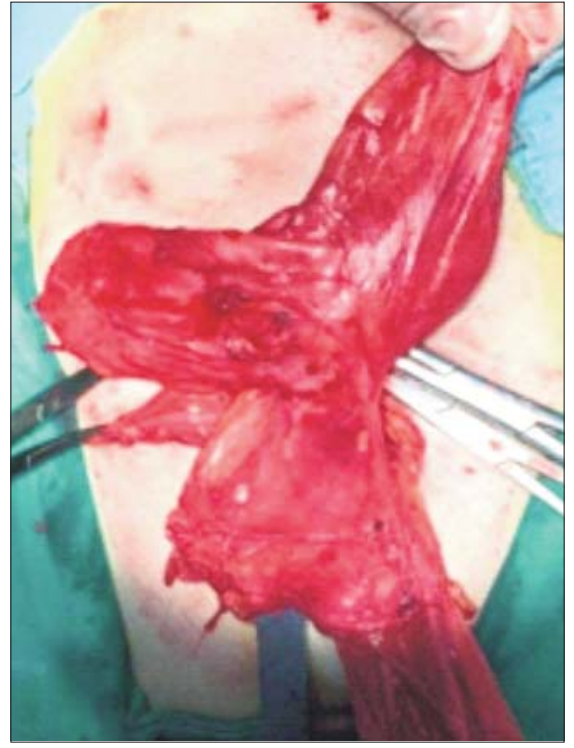

Figure 3. The groin sac 


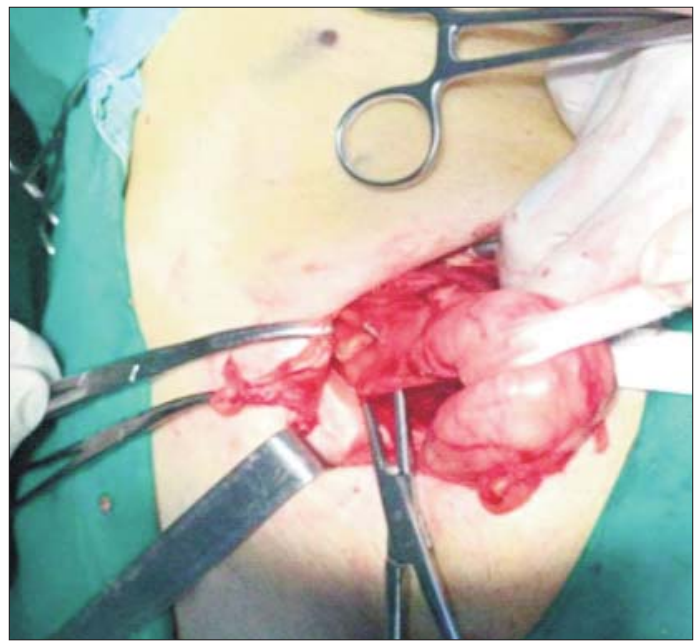

Figure 4. The resection of the cremaster muscle

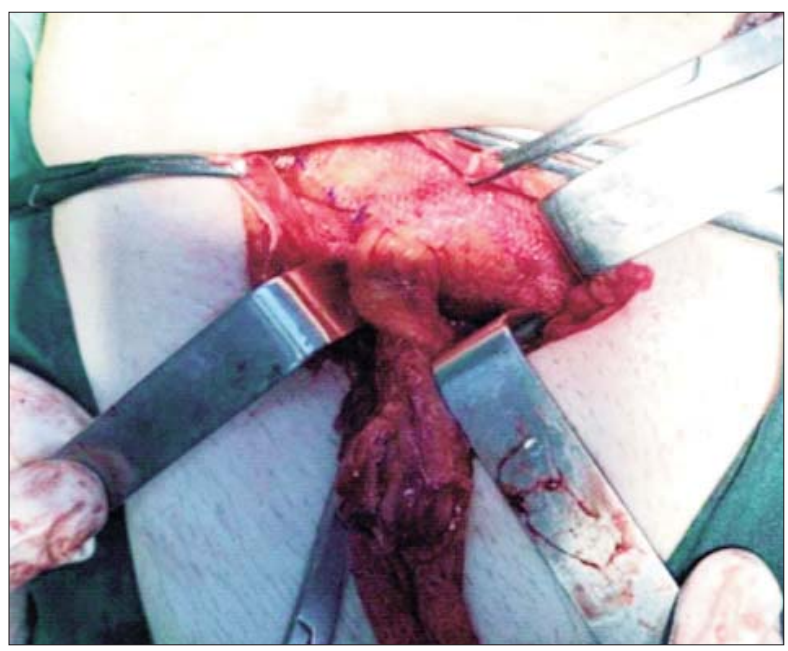

Figure 5. The deep inguinal canal ring
Subsequently, the two bands are fixed with two interrupted sutures that rebuild the deep inguinal canal ring (Fig. 5).

The reconstruction of the fascia of the external oblique muscle above the spermatic cord is also done with a Biopro 3.0 running suture which also recalibrates the superficial inguinal canal ring. The procedure is finalised with an intradermal suture. Drainage was not used in any case. The duration of the intervention was between 35 and 55 minutes.

As part of the Fast-track surgery concept the patient walks alone from the operating table to the ward.

After that the patients receive intravenous fluids and antibiotics, without any other special treatments.

Patients were discharged within two hours after getting off from the operating table, provided they had urinated. On discharge, the patients were accompanied by the next of kin and were advised to avoid driving for 24 hours.

The dressing is changed after 48 hours postoperatively, and then after 2 and 7 days to see if there are problems with the wound. Clinic follow-up was performed at 6 months, one year and two years after the surgery.

\section{Results}

The retrospective study was conducted at the Proctoven Clinic in Sibiu for a period of 5 years. 219 patients with inguinal hernia diagnosis were operated from March 2011 to March 2016. Postoperative follow-up was organised at 2 and 7 days and 6, 12 and 24 months, respectively. Of the 219 patients there were 16 women and 203 men (Fig. 6). The patients' age ranged between $18-87$ years. He operation is contraindicated in minors. Group age distribution was the following: between 20-40 years - 57 patients - $(26 \%)$, between $40^{-}$ 60 years -70 patients $(32 \%)$ and between $60^{-}$ 90 years - 92 patients - (42\%) (Fig. 7).

The significant preponderance of urban patients in the study group is due to both financial as well as access to medical treatment issues in the rural population (Fig. 8).

The most common comorbidities were: HTA, DZ, CIC, BPOC, HBP (Fig. 9).

Early postoperative complications (within 7

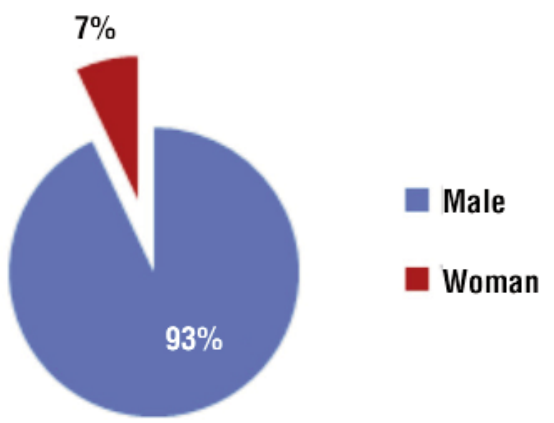

Figure 6. Gender distribution 


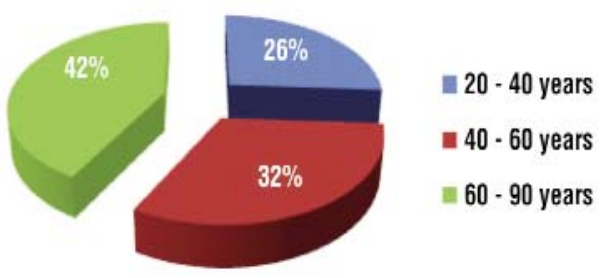

Figure 7. Distribution by age

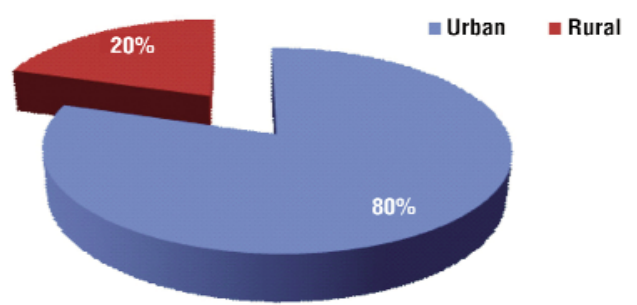

Figure 8. Distribution according the environment of origin

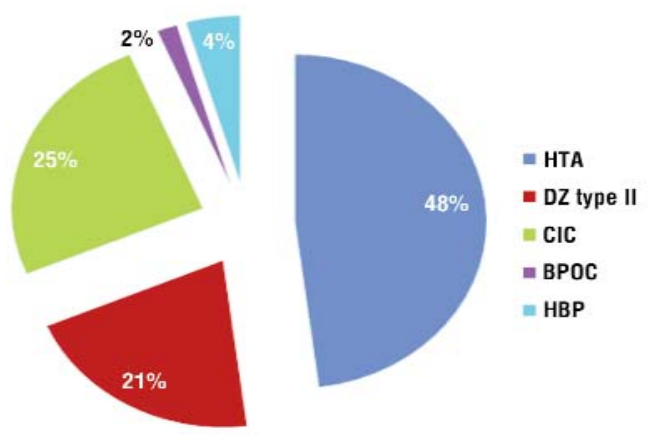

Figure 9. Comorbidities

days post surgery) occurred in 20 patients, represented by 8 patients with wound hematoma (especially those with very large inguino-scrotal hernias, difficult dissection, not using postoperative drainage) and 12 patients with wound seroma (Table 1). No postoperative wound infections were recorded.

Late postoperative morbidity was represented by chronic postoperative pain - 3 cases and cutaneous hypoesthesia - 12 cases. All cases had spontaneous resolution (Table 1).

\section{Discussions}

Clinical studies and animal experiments have shown that there is a large difference in the inflammatory capacity of the alloplastic material used, which is influenced by the density of the mesh (14). The presence of smaller holes than $1 \mathrm{~mm}$ in the mesh, produces more pronounced inflammation and fibrosis, while larger holes give less fibrotic reaction, lack of keloid scar and conserved the elasticity of the inguinal region $(1,8,14-17)$.

In our study we used exclusively alloplastic mesh with large holes.

Regarding the forming of seroma or hematoma according to Lichtenstein's alloplastic technique, compared to other conventional techniques, literature does not reveal the difference between mesh groups and those without (18-21).

We think that their appearance is more related to the application of the technique and the comorbidities and particularities of each patient than the technique itself.

In the pro-peritoneal procedures described in the classical open surgery, Nyhus, Stoppa, Rigmauld, Rives, Read, Robertson, Margoles, Malangoni and Condon, Lichtenstein and Shore, all of them being prosthetic allograft fixation and also using the oversized prosthesis, especially for bilateral hernia (Stoppa, Mahorner, Goss, Gosset, Detrie, Elghozi) (22). We preferred the notion of optimal tension or tolerated tension to the notion of tension free, due to the fact that the tissue dictates the tension that we should apply (so that the tension creates resistance).

Applying the concept of Fast Track Surgery, which involves multimodal approach to patient care, using a combination of several perioperative workouts that greatly enhance postoperative recovery (22), has helped us

Table 1. Immediate and late postoperative complications

\begin{tabular}{lc}
\hline Number of patients & 219 \\
\hline Wound hematoma & $23 \%$ \\
\hline Wound serum & $34 \%$ \\
\hline Skin hypoesthesia & $34 \%$ \\
\hline Chronic pain & $9 \%$ \\
\hline
\end{tabular}


reduce the hospitalization period to less than 3 hours.

\section{Conclusions}

We consider the practice of the Lichtenstein procedure for our patients to be extremely feasible, very well tolerated, with less than 3 hours hospitalization, with good short and long term results.

General intravenous anesthesia, combined with the inguinal regional block anaesthesia, is one of the most important factors inpatients' fast recovery and social reinsertion.

The minimal transverse incision contributes to a very good final aesthetic appearance.

The extremely accurate price/quality ratio, as well as the excellent post-operative results make the technique extremely attractive to the patients.

\section{Conflict of Interest}

The authors declare no conflicts of interests.

\section{References}

1. Tanasescu C, Boicean A, Teodoru A. Outpatient surgery for inguinal hernia. AMT. 2016;20(1):105-108.

2. Cuschieri, Giles GR, Moosa RA. The abdominal wall and hernias, in essential surgical practice, $2^{\text {nd }}$ edition. London-Boston: Editura Wright; 1988

3. EU Hernia Trialists Collaboration. Mesh compared with non-mesh methods of open groin hernia repair: systematic review of randomized controlled trials. Br J Surg. 2000;87(7):854-9.

4. Lichtenstein IL, Shulman AG, Amid PK, Montllor MM. The tension free hernioplasty. Am J Surg. 1989;157(2):188-93.

5. Mitoiu D. Tendinte actuale in tratamentul herniilor inghinale. EMCB; 2004.

6. Sabau D, Oprescu S. Elemente de chirurgie a defectelor parietale abdominale. Bucuresti: Edit. Medicala; 1989.

7. Cîmpeanu I, lurea C, Neagu N. Structuri anatomice fundamentale ale canalului inghinal. Implicatii terapeutice. A XVI-a reuniune a chirurgilor din Moldova, 19-20 mai 1988.

8. Chicea R, Chicea AL, Mihetiu A, Tantar C, Cernusca Mitaru MM, Cernusca Mitaru SI, et al. Comparative study between tissues induced immunohistochemical changes of thread granulomas and textile allografts. Materiale Plastice. 2018;55(1):99-101

9. Pregler JL, Kapur PA. The development of ambulatory anesthesia and future challenges. Anesthesiol Clin North Am. 2003;21(2):207-28.

10. Bratu D, Sabau A, Dumitra A, Sabau D, Mihetiu A, Beli L, et al. Laparoscopic surgical treatment of umbilical hernia and small eventrations with prosthetic mesh using omentum overlay. Chirurgia (Bucur). 2014;109(5):655-9.

11. Jarrett PEM. Day case surgery. Eur J of Anaesthesiology. 2001; 18:3235.

12. Nordin $\mathrm{P}$, Zetterström H, Carlsson P, Nilsson E. Cost-effectiveness analysis of local, regional and general anaesthesia for inguinal hernia repair using data from a randomized clinical trial. $\mathrm{Br} \mathrm{J}$ Surg. 2007;94(4):500-5.

13. O'Dwyer PJ, Serpell MG, Millar K, Paterson C, Young D, Hair A, et al. Local or general anesthesia for open hernia repair: a randomized trial. Ann Surg. 2003;237(4):574-9.

14. Kehlet H, Bay Nielsen M. Anaesthetic practice for groin hernia repair--a nation-wide study in Denmark 1998-2003. Acta Anaesthesiol Scand. 2005;49(2):143-6.

15. Bratu D, Boicean A, Tanasescu C, Sofariu C, Mihetiu A, Cernusca Mitaru IS, et al. Textile polypropylene allografts and their postoperative tissue reaction in the surgery of inguinal hernia. Materiale Plastice. 2017;54(1):119-121.

16. Chicea R, Bratu D, Chicea AL, Mihetiu A, Preluca V, Tantar C, et al. A comparative histologic and immunohistochemistry evaluation between normal aponeurotic tissue, fibrotic aponeurotic scars and polypropylene embedded aponeurotic scars. Materiale Plastice. 2017;54(3):510-512.

17. Fitzgibbons RJ, Giobbie-Hurder A, Gibbs JO, Dunlop DD, Reda DJ, McCarthy M Jr, et al. Watchful waiting vs repair of inguinal hernia in minimally symptomatic men: a randomised clinical trial. JAMA. 2006;295(3):285-92.

18. Grant AM, EU Hernia Trialists Collaboration. Open mesh versus non-mesh repair of groin hernia: meta-analysis of randomised trials based on individual patient data [corrected]. Hernia. 2002; 6(3):130-136

19. Schumpelick V, Nyhus LM. Meshes: benefits and risks. Heidelberg: Springer; 2006

20. EU Hernia Trialists Collaboration. Repair of groin hernias with synthetic mesh: meta-analysis of randomized controlled trials. Ann Surg. 2002;235(3):322-32.

21. Voyles CR, Hamilton BJ, Johnson WD, Kano N. Meta-analysis of laparoscopic inguinal hernia trials favors open hernia repair with preperitonealprothesis. Am J Surg. 2002;184(1):6-10.

22. Nanavati AJ, Prabhakar S. Fast-track surgery: Toward comprehensive peri-operative care. Anesth Essays Res. 2014;8(2):127-33. 